Journal of Telenursing (JOTING)

Volume 3, Nomor 1, Juni 2021

e-ISSN: 2684-8988

p-ISSN: 2684-8996

DOI: https://doi.org/10.31539/joting.v3i1.2076

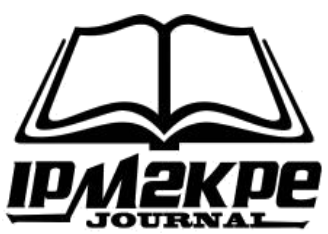

\title{
STUDI FENOMENOLOGI: PENGALAMAN KLIEN LANSIA DALAM MELAKUKAN PERAWATAN DIABETES MELLITUS TIPE 2
}

\author{
Nadirawati ${ }^{1}$, Irfan Pratama ${ }^{2}$ \\ STIKES Jenderal Achmad Yani Cimahi ${ }^{1}$ \\ Rumah Sakit Hermina Kemayoran Jakarta Pusat ${ }^{2}$ \\ irakarnain@gmail.com ${ }^{1}$
}

\begin{abstract}
ABSTRAK
Penelitian ini bertujuan untuk mendapatkan pemahaman yang mendalam tentang makna perawatan Diabetes Melitus (DM) tipe 2 untuk klien lansia di wilayah kerja puskesmas Cimahi Selatan dan bagaimana mereka memaknai pengalaman tersebut. Penelitian ini menggunakan pendekatan kualitatif dengan desain fenomenologi deskriptif dengan metode wawancara mendalam. Partisipan dalam penelitian ini adalah klien lansia dengan DM tipe 2. Data yang dikumpulkan berupa hasil rekaman wawancara dan catatan lapangan yang dianalisis dengan teknik Collaizi. Hasil penelitian ini mengidentifikasi enam tema, diantaranya yaitu; 1) respon fisik yang dialami penderita $\mathrm{DM}$; 2) respon psikologis yang dialami penderita DM; 3) kepatuhan terhadap pengobatan; 4) kepatuhan terhadap diet; 5) upaya untuk mencapai kesembuhan; 6) harapan penyandang DM. Simpulan, dari enam informan yang mengalami DM, mereka mengalami beberapa masalah fisik dan psikologis, ada yang tidak patuh dengan diet dan cara parisipan mengatasi masalah ada yang menggunakan obat farmakologis dan juga non farmakologis. Selain itu, walaupun sudah lama menderita DM, hampir semua partisipan berharap untuk sembuh dari penyakitnya.
\end{abstract}

Kata Kunci: Diabetes Mellitus Tipe 2, Kualitiatif, Merawat

\begin{abstract}
This study aims to gain an in-depth understanding of the meaning of type 2 Diabetes Mellitus (DM) treatment for elderly clients in Puskesmas Cimahi Selatan's work area and how they interpret this experience. This study used a qualitative approach with a descriptive phenomenological design with in-depth interviews. Participants in this study were elderly clients with type 2 diabetes. The data collected were in the form of recorded interviews and field notes which were analyzed using the Collaizi technique. The results of this study identified six themes, including; 1) physical response experienced by DM sufferers; 2) psychological response experienced by DM sufferers; 3) adherence to medication; 4) adherence to diet; 5) efforts to achieve healing; 6) expectations of people with DM. In conclusion, of the six informants who experienced diabetes they experienced several physical and psychological problems. Some were not obedient to the diet, and the way the parents dealt with the situation was by using pharmacological and non-pharmacological drugs. Besides, even though they have had diabetes for a long time, almost all participants hoped to recover from their illness.
\end{abstract}

Keywords: Type 2 Diabetes Mellitus, Qualitative, Caring 


\section{PENDAHULUAN}

Diabetes Mellitus (DM) tipe 2 merupakan penyakit metabolik yang sangat rentan terjadi komplikasi serius apabila penderita tidak mematuhi penatalaksanaan yang dianjurkan oleh tenaga kesehatan. Gaya hidup dan ketidakpatuhan klien dalam melakukan perawatan menyebabkan populasi diabetes mellitus terus mengalami peningkatan dari tahun ketahun. Data IDF menunjukan ada lebih 371 juta penyandang DM diseluruh dunia dan $80 \%$ terjadi di negara yang berkembang. Indonesia menempati peringkat ke enam di dunia dengan prevalensi penyandang DM pada tahun 2017 berjumlah 10,3 juta jiwa, meningkat menjadi 16 juta jiwa pada tahun 2018 dan diestimasikan akan meningkat menjadi 21,3 juta jiwa pada tahun 2030 (IDF Atlas, 2019).

Berdasarkan hasil Riskesdas pada tahun 2018, penderita DM tipe 2 mengalami peningkatan dengan prevalensi $10,9 \%$. Hal ini disebabkan oleh kurangnya dukungan keluarga dan kurangnya kepatuhan penderita terhadap penatalaksanaan DM tipe 2. Keadaan ini didukung oleh data Riskesdas yang melaporkan bahwa pasien yang tidak patuh karena sudah merasa sehat sebanyak 50,4\%, tidak rutin berobat ke fasilitas pelayanan kesehatan sebanyak 30,24\%, sering lupa berobat 18,77\% dan tidak mampu membeli obat secara rutin 8.45\% (Kementrian Kesehatan RI, 2018). Hasil laporan Dinas Kesehatan Kota Cimahi tahun 2016 - 2018, penyakit DM tipe 2 mengalami peningkatan dalam kurun waktu 3 tahun terakhir dengan hasil yang didapat adalah 7.280 pada tahun 2016, 8.982 pada tahun 2017 dan 11.701 pada tahun 2018. Daerah Cimahi Selatan memiliki jumlah penderita DM tipe 2 sebanyak 338 penderita.

Siregar (2019) menyatakan bahwa kebanyakan klien dengan DM tipe 2 memiliki pemahaman yang kurang terkait dengan penatalaksanaan DM. Selain itu faktor lingkungan dan gaya hidup yang tidak sehat seperti makan berlebihan, kurangnya melakukan aktivitas dan stress sangat berperan ikut terhadap terjadinya komplikasi pada DM. Penderita DM sendiri kurang menunjukan kepedulian terhadap penatalaksanaan DM, bahkan tidak sedikit dari mereka yang mengalami komplikasi karena kurangnya informasi mengenai penyakit DM (Anwar \& Karota, 2019). Beberapa kasus menunjukkan bahwa ada penderita yang sudah mengetahui tentang DM, namun mereka tetap tidak melaksanakan apa yang dianjurkan oleh tenaga kesehatan dengan baik. Meskipun DM tidak dapat menyebabkan kematian secara langsung, namun apabila cara merawat yang tidak tepat akan berakibat fatal yaitu banyaknya komplikasi yang mungkin terjadi bagi penyandang DM tipe 2. Komplikasi yang bisa terjadi diantaranya yaitu komplikasi mikrovaskuler dan makrovaskular. Komplikasi mikrovaskuler antara lain retinopati yang dapat menyebabkan kebutaan, nephropati sebagai triger penyakit ginjal, impoten dan neuropati (Rosyid et al., 2020).

Upaya yang bisa dilakukan untuk mengatasi penderitaan klien dengan DM yang sudah kronis sangat sedikit. Sebenarnya upaya penataklaksanaan klien DM lebih banyak difokuskan pengobatan untuk memperbaiki resistensi insulin dan memperbaiki fungsi sel beta. Selain itu penyandang DM juga harus tetap memperhatikan perubahan yang mendasar dalam pengelolaan pola hidup diantaranya pola makan dan olah raga yang teratur. Perubahan mendasar terkait pola hidup terutma diet dan olahragalah yang seringkali terlewatkan oleh klien, sehingga banyak klien DM yang mengalami komplikasi akibat penyakit ini. Hal ini tentu sangat meresahkan, sebagai seorang perawat harus bisa melakukan pencegahan yang bersifat preventif untuk mengedukasi masyarakat agar komplikasi komplikasi akibat diabetes tidak terus meningkat (Susanti, 2018). 
Hal ini tentu sesuai dengan tanggung jawab seorang perawat yaitu melakukan identifikasi kebutuhan komunitas; mengidentifikasi; merencanakan, melakukan implementasi dan evaluasi populasi yang fokus intervensinya adalah dengan menekankan pada aspek promosi kesehatan bagi populasi yang berisiko. Penyakit DM ini tidak dapat disembuhkan akan tetapi sangat potensial untuk didapat dicegah, karena DM adalah penyakit yang berhubungan dengan gaya hidup, maka keberhasilan pengelolaan DM sangat tergantung pada klien itu sendiri dalam mengubah perilakunya (Anwar \& Karota, 2019). Oleh karena itu, seorang perawat harus dapat berperan dalam pencegahan terhadap penyakit degenerative dengan melakukan pelayanan kesehatan yang mengutamakan pencegahan primer, sekunder dan tersier terutama terhadap populasi berisiko sehingga dapat merubah prilaku masyarakat yang tidak sehat kearah yang lebih sehat (Damayanti \& Rahil, 2018). Untuk mencapai hal tersebut tentu tidak mudah, dibutuhkan suatu penggalian yang mendalam dalam menyelesaikan suatu masalah yang ada di komunitas.

Penelitian kualitatif sebelumnya banyak mengacu kepada respon fisik dan psikologis yang terjadi pada pasien DM saja, sehingga belum dapat mendeskripsikan perawatan DM di rumah secara keseluruhan seperti penelitian yang dilakukan oleh Rusdaningseh (2018) yang melihat respon fisik dan psikolgis saja. Dengan demikian perlu dilakukan penggalian lebih mendalam mengenai aspek lainnya seperti perawatan di rumah, pengobatan dan diet yang dilakukan oleh pasien DM. Penggalian aspek tersebut dapat dilakukan dengan menggali fenomena berkenaan dengan pemahaman bagaimana keseharian, dunia kehidupan penderita DM baik itu sebelum kejadian dan sesudah kejadian sehingga peneliti dapat mengungkap arti dan makna, konsep atau fenomena pengalaman yang didasari oleh kesadaran yang terjadi pada individu.

Saat ini penelitian melalui pendekatan ilmu sosial (kualitatif) jarang dipahami oleh petugas kesehatan. Hal ini bisa berdampak pada program pengobatan kurang berjalan dengan baik karena tidak bisa menggali lebih dalam dari arti dan makna persepsi masyarakat terhadap penyakit itu sendiri. Padahal studi kualitatif mampu mengungkap fakta, bagaimana persepsi individu terhadap penyebab penyakit arti dan makna dari prevensi yang dilakukan, apa makna penyakit terhadap diri sendiri, apa konsekuensi sosial dari penyakit serta kenapa seseorang menolak program pengobatan. Penelitian kualitatif dapat menjelaskan masalah-masalah manusia atau sosial dengan menciptakan gambaran menyeluruh dan komplek dan terperinci yang diperoleh dari para informan, sehingga dengan pemahaman yang mendalam, seorang perawat dapat melakukan pencegahan terhadap penyakit dengan melakukan pelayanan kesehatan yang mengutamakan pencegahan primer, sekunder dan tersier terutama terhadap populasi berisiko. Oleh karena itu, peneliti tertarik untuk mengkaji lebih dalam mengenai pemahaman tentang makna perawatan penderita DM tipe 2 untuk klien lansia di wilayah kerja puskesmas Cimahi Selatan dan cara mereka memaknai pengalaman tersebut.

\section{METODE PENELITIAN}

Penelitian ini menggunakan metode kualitatif dengan pendekatan fenomenologi deskriptif. Peneliti mengeksplorasi secara langsung pengalaman dari seorang partisipan yang memiliki makna yang terdiri dari perasaan partisipan, ingatan, sebuah tindakan, kepercayaan dan sebuah keputusan- Teknik pengambilan sampel yang digunakan oleh peneliti adalah purposive sampling. Saturasi data terjadi pada partsipan ke lima dan ditambah satu partisipan sehingga partisipan yang terlibat pada penelitian ini sebanyak enam orang dan memiliki kriteria inklusi terdiri dari: 1) penderita DM tipe 2 dengan 
kurun waktu penderita minimal $\geq 6$ bulan; 2) tidak mengalami komplikasi yang berat dan tidak mengalami koma seperti stroke parah, penyakit jantung dan diabetes ketoasidosis; 3) mampu menceritakan pengalamannya.

Data diambil melalui wawancara mendalam dan direkam memakai handphone dengan aplikasi voice recorder. Sesi wawancara dilakukan selama kurang lebih 60 menit di rumah partisipan. Selama proses wawancara, peneliti mencatat bagaimana tingkah laku partisipan di catatan lapangan (field note). Wawancara dihentikan ketika data yang didapat sudah cukup dan tidak ada lagi informasi yang didapat. Analisa data yang digunakan adalah metode colaizzi, peneliti membaca kembali transkrip atau hasil wawancara lalu peneliti mengidentifikasi kata kunci dari partisipan yang bermakna. Kemudian dibentuk menjadi kategori, setelah itu kategori yang memiliki makna yang sama dibentuk menjadi subtema. Selanjutnya dari subtema yang didapat lalu dianalisis menjadi tema. Setelah itu, peneliti mendeskripsikan dalam bentuk narasi hal ini dilakukan untuk menggabungkan seluruh tema dan subtema untuk menggambarkan secara menyeluruh pengalaman klien merawat DM tipe 2.

\section{HASIL PENELITIAN}

Partisipan yang mengkuti penelitian terdiri dari enam klien lansia yang mengalami DM tipe 2 mayoritas partisipan berjenis kelamin perempuan. Seluruh partisipan ratarata mengalami DM tipe 2 lebih dari enam bulan. Partisipan bersuku Sunda sehingga pada saat wawancara berlangsung bahasa yang digunakan yaitu Bahasa Sunda yang dicampur dengan Bahasa Indonesia. Partisipan seluruhnya beragama Islam dan bertempat tinggal di Kota Cimahi khususnya di Kelurahan Utama Kecamatan Cimahi Selatan, Jawa Barat. Partisipan menjalani masa pengobatan selama menderita DM dimulai dari satu sampai sepuluh tahun. Terdapat enam tema yang terindentifikasi dari pengalaman klien lansia merawat DM tipe 2 di wilayah kerja Puskesmas Cimahi Selatan, diantaranya yaitu: 1) respon fisik yang dialami penderita DM; 2) respon psikologis yang dialami penderita DM; 3) kepatuhan terhadap pengobatan; 4) kepatuhan terhadap diet; 5) upaya untuk mencapai kesembuhan; 6) harapan penyandang DM.

\section{Respon Fisik yang Dialami Penderita DM}

Respon fisik yang dialami oleh partisipan sangat beragam. Tema yang terbentuk diambil dari kesimpulan pernyataan partisipan yang terbagi menjadi dua kategori respon fisik, diantaranya keluhan ketika pertama kali terkena DM. Partisipan pada saat diwawancara tidak menyadari bahwa mereka memiliki DM tipe 2, keluhan yang dirasa diantaranya lemas, sering buang air kecil, serta haus. Hasil wawancara pada keenam partisipan rata-rata mereka merasakan keluhan fisik yang sama pada saat pertama kali terkena DM tipe 2 . Keluhan yang dirasakan oleh partisipan adalah sebagai berikut:

Lemes terus pengennya tidur gitu.

(Wawancara dengan informan 1 Ny. ER pada tanggal 17 Mei 2017)

Lemes sama pusing terus lapar haus terus suka pengen pipis (buang air kecil).

(Wawancara dengan informan 2 Ny. A pada tanggal 18 Mei 2017)

Waktu pertama-pertamanya mah gitu eeee..... shhh...eee lemes pusing gitu.

(Wawancara dengan informan 3 Ny. MK pada tanggal 19 Mei 2017

Lemes...terus sama minum teh terus weeh, sama pipis terus...haus terus... gitu weh terus.

(Wawancara dengan informan 4 Tn. S pada tanggal 20 Mei 2017) 
Suka lemes kadang sampe badan bergetar sama puyeng.

(Wawancara dengan informan 5 Ny. I pada tanggal 21 Mei 2017)

Sebelum ibu tau kena gula teh...ya suka kencing terus kalo malem-malem...abis itu haus...terus sama lemes.

(Wawancara dengan informan 6 Ny T pada tanggal 23 Mei 2017)

Berdasarkan ungkapan dari keenam partisipan, komplikasi yang dirasakan setelah lebih dari 1 tahun menyandang DM merasakan berat badannya mengalami penurunan, mata kabur, sering kesemutan seperti yang diungkapkan oleh partisipan 1, 4 dan 6 . Berikut hal yang diungkapkan oleh partisipan:

Lemes terus pengennya tidur gitu.... mata burem, kaki seperti kesemutan...efeknya ke badan jadi kurus dari $80 \mathrm{Kg}$ sekarang jadi $63 \mathrm{Kg}$.

(Wawancara dengan informan 1 Ny. ER pada tanggal 17 Mei 2017)

Lemes....terus sama minum teh terus wee, sama pipis terus..haus terus... gitu weh terus... berat badan jadi turun dari $70 \mathrm{Kg}$ jadi $48 \mathrm{Kg}$.

Wawancara dengan informan 4 Tn S pada tanggal 20 Mei 2017)

Suka lemes kadang sampe badan bergetar sama puyeng...berat badan jadi turun. (Wawancara dengan informan 5 Ny. I pada tanggal 21 Mei 2017)

Partisipan 1 baru menyadari bahwa dia terkena DM setelah menyadari ada penurunan Berat badan yang drastis, seperti ungkapannya di bawah ini:

Efeknya ke badan jadi kurus dari $80 \mathrm{Kg}$ sekarang jadi $63 \mathrm{~K}$, baru tau kena DM. (Wawancara dengan informan 1 Ny. ER pada tanggal 17 Mei 2017)

Hasil wawancara dari enam partisipan ditemukan bahwa mereka merasakan kondisi tubuh yang sangat beragam setelah beberapa lama terkena DM, diantaranya seperti marah, sakit kepala, lemas dan sering marasa lapar. Hal ini diungkapkan oleh partisipan 2 sampai 6 sebagai berikut:

Ya gitu weh lemes pusing engga mau apa-apa....rasanya teh mau marah-marah aja.

(Wawancara dengan informan 2 Ny. A pada tanggal 18 Mei 2017)

Lemes terus pusing tapi engga sampe pingsan.

(Wawancara dengan informan 3 Ny. MK pada tanggal 19 Mei 2017)

Lemes terus badan tuh... tapi ada satu waktu pengen makan terus.

(Wawancara dengan informan 4 Tn S pada tanggal 20 Mei 2017)

Lemes weh engga bisa gerak...kalo jalan juga kaya ada yang ngiket kaki teh kaku.

Wawancara dengan informan 5 Ny. I pada tanggal 21 Mei 2017)

Da ai (kalo dari) diabetesnya mah cuman kerasa di mata kadang burem kadang engga.

(Wawancara dengan informan 1 Ny. ER pada tanggal 17 Mei 2017)

Kadang ibu mah suka pusing sampe ini teh dingin (menyentuh kening yang terasa dingin).

(Wawancara dengan informan 6 Ny. T pada tanggal 23 Mei 2017)

\section{Respon Psikologis yang Dialami Penderita DM}

Respon psikologis yang teridentifikasi saat pertama kali dinyatakan terkena DM bervariasi. Respon yang muncul dikategorikan menjadi 4 kategori saat mengalami DM diantaranya: menyangkal (denial), menerima (acceptance), depresi, dan marah. Respon 
menyangkal sangatlah umum bagi penderita DM, karena banyak dari mereka tidak menyadari bahwa mereka sudah menderita diabetes. Ketika terdiagnosa oleh seorang tenaga medis hal yang paling pertama kali pasien akan menyangkal sebab selama ini pasien merasa tubuhnya sehat tidak mengalami keluhan yang signifikan apalagi sampai mengarah ke penyakit DM. Partisipan yang merasa tidak menyangka menyatakan hal sebagai berikut:

Ya perasaan mah waktu itu kaget punya gula darah 500 lebih gitu, langsung we ke puskesmas....terus hasilnya sama...dulunya ibu ga percaya tapi pas ke puskesmas percaya we ada gula gitu.

(Wawancara dengan informan 1 Ny. ER pada tanggal 17 Mei 2017)

Yaaa....da gatau bakalan kena penyakit kaya gitu...tapi cape sama minum sama haus terus...da gatau juga bakalan kena.

(Wawancara dengan informan 4 Tn S pada tanggal 20 Mei 2017)

Ya engga percaya weh soalnya udah puluhan tahun...baru punya penyakit kaya gitu.

(Wawancara dengan informan 5 Ny. I pada tanggal 21 Mei 2017)

Awalnya mah engga tau bakalan kena gula...kenapa bisa yah kena penyakit seperti itu.

(Wawancara dengan informan 6 Ny. T pada tanggal 23 Mei 2017)

Respon menerima akan dialami oleh klien penderita diabetes setelah mereka menyadari bahwa apabila terus-terusan menyangkal, maka hal itu tidak akan merubah keadaan kecuali diri mereka sendiri yang harus mengubahnya. Berikut adalah ungkapan partisipan 1, 3, 4, 5 dan 6 mengenai respon acceptance:

Ya kalo makan mah makan weh...da kalo meninggal dari diabetes mah bukan urusan dokter da itu mah udah patokannya...udah pasrah ibu mah.

(Wawancara dengan informan 1 Ny. ER pada tanggal 17 Mei 2017)

Ah engga...hahaha...udah ajalah da udah tua...haha biarin aja.

(Wawancara dengan informan 3 Ny. MK pada tanggal 19 Mei 2017)

Da ai berobat wae teh bosen bapa...tapi da mau gimana lagi wayahna (nerima yang udah terjadi) weh. (Kalo berobat bapak sudah bosan tapi mau gimana lagi) (Wawancara dengan informan 4 Tn S pada tanggal 20 Mei 2017)

Da ai rutin mah emang harus ya...tapi da ai namanya orang males harus gimana...biarin ah yang penting mah sehat.

(Wawancara dengan informan 5 Ny. I pada tanggal 21 Mei 2017)

Setelah tau mah ya mau gimana lagi....da engga bisa apa-apa.

(Wawancara dengan informan 6 Ny. T pada tanggal 23 Mei 2017)

Lansia sangatlah rentan mengalami depresi terutama ketika mengalami berbagai macam penyakit degeneratif khususnya DM. Hal ini dikarenakan pada penyakit ini banyak sekali hal yang harus dipertimbangkan oleh penderita untuk menjaga kadar gula darah agar tetap stabil. Respon sedih dialami oleh partisipan 2 saat beliau terdiagnosa DM, adapun ungkapan yang diutarakan oleh partisipan sebagai berikut:

Yaaaa sedih we tau dari puskesmas teh nangis (mata yang sudah berkaca-kaca).

(Wawancara dengan informan 2 Ny. A pada tanggal 18 Mei 2017) 

berikut:

Respon takut dan khawatir dirasakan oleh partisipan 3 dengan ungkapan sebagai

Ya perasaan mah gitu weh...khawatir sama takut gitu.

(Wawancara dengan informan 3 Ny. MK pada tanggal 19 Mei 2017)

Yyaaaa takut kematian aja takut lebih parah.

(Wawancara dengan informan 3 Ny. MK pada tanggal 19 Mei 2017)

Setiap individu khususnya lansia memiliki presepsi yang sangat beragam terutama pada penyakit yang dideritanya. DM merupakan penyakit yang memerlukan waktu sangat panjang untuk merawatnya, sehingga terkadang lansia yang menderita penyakit ini sering merasa kesal. Berikut adalah ungkapan partisipan pada saat dilakukan wawancara:

Rasanya teh mau marah-marah aja.

(Wawancara dengan informan 2 Ny. A pada tanggal 18 Mei 2017)

Suka kesel juga sama penyakit ini tuh pengennya kaya gimana.

(Wawancara dengan informan 4 Tn S pada tanggal 20 Mei 2017)

\section{Kepatuhan terhadap Pengobatan}

Masa perawatan DM yang cukup lama bahkan perawatannya bisa sampai seumur hidup membuat para penderita merasa bosan terhadap pengobatan yang sedang dijalaninya. Terdapat 2 kategori penyebab ketidakpatuhan penderita DM, diantaranya: 1) internal, tidak mengonsumsi obat sesuai dengan anjuran; 2) eksternal, tidak melaksanakan pengobatan sesuai anjuran. Berdasarkan kategori tema yang telah dibentuk dari pernyataan partisipan ditemukan bahwa beberapa dari mereka mengeluh jenuh dengan pengobatan yang dijalani. Selain jenuh, hal yang paling sering dialami oleh partisipan adalah sering lupa untuk meminum obat sebelum makan bahkan ada yang menentukan dosisnya sendiri sesuai dengan kemauannya. Adapun partisipan yang mengeluh jenuh atau bosan untuk mengonsumsi obat diantaranya:

Tapi da gitu..meskipun terus-terusan minum obat juga engga ilang jadi bosen minum obat juga.

(Wawancara dengan informan 1 Ny. ER pada tanggal 17 Mei 2017)

Ada rasa bosen juga soalnya udah terlalu sering juga ibu minum obatnya. (Wawancara dengan informan 3 Ny. MK pada tanggal 19 Mei 2017)

Sebelumnya mah engga pernah minum obat...bosen.

(Wawancara dengan informan 4 Tn S pada tanggal 20 Mei 2017)

Terus obat juga sebenernya mah udah ga mau minum ah....di tenggorokkan teh udah geli.

(Wawancara dengan informan 5 Ny. I pada tanggal 21 Mei 2017)

Ah da engga terasa apa-apa minum obat juga... jadi jenuh ke ibunya juga. (Wawancara dengan informan 6 Ny. T pada tanggal 23 Mei 2017)

Pernyataan lain yang diutarakan pasrtisipan yaitu lupa untuk mengonsumsi obat diantaranya:

Sering ibu mah, da suka lupa buat minum obat...itu aja masih banyak da minum obat teh lupa.....uhuk (batuk).

(Wawancara dengan informan 1 Ny. ER pada tanggal 17 Mei 2017)

Kadang-kadang bapa suka lupa buat minum de.

(Wawancara dengan informan 4 Tn S pada tanggal 20 Mei 2017) 
Partisipan juga ada yang dengan sengaja tidak mengonsumsi obat dengan berbagai macam alasan. Padahal partisipan sendiri sudah memahami bahwa obat tersebut dapat mengontrol gula darah. Ungkapan partisipan tersebut diantaranya:

Da males udah dua minggu ibu ga minum obat...ya karena males...gula darah ibu naik lagi.

(Wawancara dengan informan 3 Ny. MK pada tanggal 19 Mei 2017)

Udah beberapa hari ada meren seminggu engga minum obat...waktu itu juga sampe empat bulan engga berobat.

(Wawancara dengan informan 6 Ny. T pada tanggal 23 Mei 2017)

Presepsi yang kurang tepat pada reaksi obat mempengaruhi kepatuhan terhadap pengobatan. Hal ini diutaran oleh beberapa partisipan diantaranya:

Ah da obatnya gitu-gitu aja kan.....engga ada yag bagus cuman itu aja yang tablet.

(Wawancara dengan informan 1 Ny. ER pada tanggal 17 Mei 2017)

Ya sama aja ...obat tuh engga begitu langsung sembuh.

(Wawancara dengan informan 2 Ny. A pada tanggal 18 Mei 2017)

Semuanya diminum tapi tetep aja engga ada perubahan...jadi bosen ke bapanya juga.

(Wawancara dengan informan 4 Tn S pada tanggal 20 Mei 2017)

Diminum juga da engga terasa apa-apa biasa aja...malahan itu obatnya masih ada.

(Wawancara dengan informan 6 Ny. T pada tanggal 23 Mei 2017)

Lingkungan menjadi salah satu penyebab eksternal tidak melaksanakan pengobatan sesuai anjuran tenaga kesehatan. Beberapa hal yang menjadi penyebab eksternal yang disebabkan oleh lingkungan diantaranya antrian yang cukup panjang sehingga dapat membuang waktu partisipan dan banyak energi yang terkuras selama antri berjam-jam. Berikut gagasan menurut para partisipan mengenai kondisi tersebut:

Bosen ngantrinya....ya mana lapar, pusing...coba bayangin dari seratus orang yang daftar dikali setengah jam kan lumayan lama itu nunggunya.

(Wawancara dengan informan 2 Ny. A pada tanggal 18 Mei 2017)

Kalo abis obatnya males ke puskesmasnya apalagi kalo antriannya banyak suka pusing.

(Wawancara dengan informan 4 Tn S pada tanggal 20 Mei 2017)

Ya engga tau karena penuh terus disananya banyak orang terus kadang suka kelamaan sampe pusing.

(Wawancara dengan informan 5 Ny. I pada tanggal 21 Mei 2017)

\section{Kepatuhan terhadap Diet}

Kunci utama untuk menurunkan tingkat keparahan pada DM bukanlah hanya dari obat-obatan saja melainkan diet merupakan metode yang bisa diaplikasikan oleh para penderita dalam kehidupan sehari-hari. Ketidakpatuhan terhadap diet yang dapat mengakibatkan kadar gula darah menjadi tidak stabil terbagi menjadi 2 kategori diantaranya: perilaku tidak melaksanakan diet dan penyebab tidak melaksanakan diet. Kedisiplinan penderita diabetes menjadi salah satu kunci keberhasilan dalam memenejemen kadar gula darah agar tetap stabil. Namun dalam pelaksanaannya 
bukanlah hal yang mudah bagi penderita DM. Beberapa gagasan mengenai prilaku partisipan tidak mengikuti diet yang dianjurkan diantaranya:

Engga pernah dipantang (dijaga) dimakan we...ibu mah sering konsumsi minuman dingin kaya fanta, teh gelas pokonya minuman ringan.

(Wawancara dengan informan 1 Ny. ER pada tanggal 17 Mei 2017)

Ibu mah engga pernah diapain sih namanya teh....pokonya mah ibu mah engga diprogram....bebas mau makan teh....pokonya mah setelah keluar dari rumah sakit teh ibu engga ditentukan kalo makan.

(Wawancara dengan informan 3 Ny. MK pada tanggal 19 Mei 2017)

Kadang suka sembunyi-sembunyi bawa makan yang manis dari warung....bawaanya pengen kopi terus.

(Wawancara dengan informan 4 Tn S pada tanggal 20 Mei 2017)

Terus kalo lagi stabil ibu mah suka minum kopi good day tapi ga terlalu manis nyeduhnya.

(Wawancara dengan informan 5 Ny. I pada tanggal 21 Mei 2017)

Makan nasi beureum terus makan nasi anu ditiiskeun tapi da bosen ibu teh jadi weh makan semaunya....malahan ibu mah ga ada diet-dietan...makan aja sampe nambah.

(Wawancara dengan informan 6 Ny. T pada tanggal 23 Mei 2017)

Gagasan yang lain pun diutarakan oleh partisipan mengenai tidak bisa menahan keinginan pribadi terutama mengonsumsi makanan dan minuman kesukaan partisipan diantaranya:

Suka tapi engga terlalu banyak gitu...tapi kalo kopi ibu mah engga bisa berhenti. (Wawancara dengan informan 1 Ny. ER pada tanggal 17 Mei 2017)

Terus ibu mah kan suka sama teh manis anget-anget...kadang sibapa mah suka bikin ngiler kalo lagi bikin teh manis. Kalo lagi pengen mah suka beli di warung.

(Wawancara dengan informan 2 Ny. A pada tanggal 18 Mei 2017)

Mau ditahan juga susah bawaannya teh pengen makan terus....ada satu hari tuh sampe empat kali makan.

(Wawancara dengan informan 4 Tn S pada tanggal 20 Mei 2017)

Kalo lagi mau pisan mah paling ibu makan sedikit aja kaya misalnya susu kental manis terus kopi ada sisa dari bapa yaudah ibu minum.

(Wawancara dengan informan 6 Ny. T pada tanggal 23 Mei 2017)

Penderita DM diharuskan untuk melaksanakan diet, akan tetapi tidak sedikit dari para penderita yang tidak mematuhi hal tersebut. Beberapa penyebab tidak melaksanakan diet yang diutarakan partisipan dengan alasan yang sangat beragam:

Pertama mah dilakuin, sehari dua hari...cuman kesananya engga... da atuh (soalnya) biayanya...susu harus beli...da bapanya udah enga kerjakan....kesininya mah minum kopi lagi.

(Wawancara dengan informan 1 Ny. ER pada tanggal 17 Mei 2017)

Kalo makan ga pernah ada takarannya...da kalo ditakar gitu mah ribet. (Wawancara dengan informan 3 Ny. MK pada tanggal 19 Mei 2017)

Soalnya bingung juga...kalo nahan lapar susah...kadang suka debat sedikit sama istri.

(Wawancara dengan informan 4 Tn S pada tanggal 20 Mei 2017) 
Perasaan jenuh menjalani diet pun menjadi penyebab partisipan tidak disiplin pada diet yang harus dijalani, dibawah ini merupakan ungkapan partisipan mengenai kejenuhan yang dialaminya :

Makanan dijaga...cuman kesininya mah engga..da udah tau kena diabetes jadi ngerasanya udah ga aneh.

(Wawancara dengan informan 1 Ny. ER pada tanggal 17 Mei 2017)

Terkadang bosen pengen makan yang lain...da atuh terus makan yang itu-itu aja. (Wawancara dengan informan 2 Ny. A pada tanggal 18 Mei 2017)

Engga tau atuh hahahaha....males aja mungkin ibunya sama bosen.

(Wawancara dengan informan 3 Ny. MK pada tanggal 19 Mei 2017

Da sama makanan teh sebenernya mah udah bosen.

(Wawancara dengan informan 5 Ny. I pada tanggal 21 Mei 2017)

\section{Upaya untuk Mencapai Kesembuhan}

Terapi komplementer menjadi salah satu pengobatan alternatif yang banyak dipilih oleh beberapa partisipan saat peneliti melakukan wawancara. Selain harga yang terjangkau terapi ini bisa dilakukan di rumah misalnya membuat minuman yang berbahan dasar dari herbal. Pada tema ini didalamnya terbentuk 2 kategori diantaranya: Upaya untuk menstabilkan gula darah dengan terapi komplementer dan hasil yang dirasakan pasien setelah terapi komplementer. Berbagai macam upaya menstabilkan gula darah dapat dilakukan oleh para penderita DM tipe 2 salah satunya yaitu dengan terapi komplementer. Tidak sedikit dari para partisipan menggunakan terapi ini demi tercapainya kesembuhan terhadap penyakit yang sedang dialaminya. Dibawah ini merupakan ungkapan partisipan mengenai upaya untuk menstabilkan gula darah dengan terapi komplementer dan asil yang dirasakan pasien setelah terapi komplementer

Udah terapi...terapi panas itu yang di Pasar Atas...terapi batu giok....terapi uap air...mmmm sama terapi telor. Suka olahraga juga senam lansia tiap minggu. (Wawancara dengan informan 1 Ny. ER pada tanggal 17 Mei 2017)

Kalo pengobatan mah udah banyak ibu mah...minum obat tradisional, minum yang pahit-pahit, diurut (dipijat) sagala ibu mah....berobat ke orang pintar....pokonya kemana aja ibu mah dilakukan.

(Wawancara dengan informan 2 Ny. A pada tanggal 18 Mei 2017)

Kata tetangga mah minum dadaunan semacam babadotan....terus minum yang pait-pait.

(Wawancara dengan informan 4 Tn S pada tanggal 20 Mei 2017)

Kalau mau minum teh suka pake tropicana slim (gula khusus diabetes) dibeliin sama anak.

(Wawancara dengan informan 5 Ny. I pada tanggal 21 Mei 2017)

Terapi diurut (dipijat)...terapi di setrum....terus beli alat ini nih yang dipake sama ibu (sambil melihatkan sebuah remot yang tersambung kabel dengan sendal) minum yang pait-pait.

(Wawancara dengan informan 6 Ny. T pada tanggal 23 Mei 2017)

Respon tubuh yang dihasilkan dari terapi komplementer pada tiap partisipan sangatlah beragam, ada yang mengatakan bahwa sudah mengalami perkembangan setelah melakukan terapi bahkan ada yang menjadi lebih buruk kondisinya setelah melakukan terapi. Hal ini sesuai dengan ungkapan berikut ini: 
Yaa enakanlah...waktu itu mah abis terapi teh ya langsung menggigil 3 hari, katanya mah itu reaksi terapinya.

(Wawancara dengan informan 1 Ny. ER pada tanggal 17 Mei 2017)

Ya enak aja ke badan, engga pusing banget kepala terus engga lemes. (Wawancara dengan informan 2 Ny. A pada tanggal 18 Mei 2017)

Yaaa.. ada yang kerasa enak ada yang engga terasa....jadi engga tetap pengaruhnya tuh.

(Wawancara dengan informan 4 Tn S pada tanggal 20 Mei 2017)

Tidak semua partisipan merasakan dampak yang positif setelah melakukan pengobatan komplementer. Beberapa partisipan mengungkapkan bahwa setelah dilakukan pengobatan komplementer, kondisi tubuh yang dirasakan mengalami penurunan:

Kalo gula puasa mah suka turun dulu 170,145,135,120 terus bulan kemaren 119 tapi setelah minum oabt herbal sekarang naik lagi 208.

(Wawancara dengan informan 5 Ny. I pada tanggal 21 Mei 2017)

Engga ada perubahan....gini aja weh...malah tambah parah...ngomong jadi kaya yang gerogi gitu.

(Wawancara dengan informan 6 Ny. T pada tanggal 23 Mei 2017)

\section{Harapan Penyandang DM}

Selama menderita DM tipe 2, setiap partisipan memiliki sebuah keinginan yang besar yaitu memiliki tubuh yang sehat seperti sebelum memiliki DM. Tema harapan dibentuk dari hasil kesimpulan pernyataan partisipan. Berikut adalah harapan yang diinginkan oleh para partisipan penelitian:

Hmmmmmm.....keinginan mah pengen sembuh... sekarang mah gini aja kalo ada senam ibu mah ikut.

(Wawancara dengan informan 1 Ny. ER pada tanggal 17 Mei 2017)

Perasaan mah ya pengen sembuh aja ibu mah.

(Wawancara dengan informan 2 Ny. A pada tanggal 18 Mei 2017)

Tapi alhamdulillah ibu mah luka juga engga terlalu lama sembuhnya gitu...harapan ibu mah ya pengen sembuh total.

(Wawancara dengan informan 3 Ny. MK pada tanggal 19 Mei 2017)

Yaaaaa asalnya mah engga rutin...tapi sekarang mah rutin kan bapa pengen sehat lagi.

(Wawancara dengan informan 4 Tn S pada tanggal 20 Mei 2017)

Ya masih dijalani mas....da pengen sembuh atuh...da cape atuh kalo sakit-sakitan the, pengen normal biar bisa kerja lagi.

(Wawancara dengan informan 5 Ny. I pada tanggal 21 Mei 2017)

Tapi da sabenerna mah ibu teh hoyong damang (pengen sembuh)...cuman ibu teh susah ngejaga makanan.

(Wawancara dengan informan 6 Ny. T pada tanggal 23 Mei 2017) 


\section{PEMBAHASAN}

Hasil penelitian dengan pendekatan fenomenologi yang berjudul pengalaman klien lansia merawat DM tipe 2 di wilayah kerja puskesmas Cimahi selatan, telah teridentifikasi tema utama sebanyak enam tema. Berikut adalah penjelasan mengenai tema yang dihasilkan dari penelitian ini:

\section{Respon Fisik yang Dialami Penderita DM}

DM tipe 2 merupakan kegagalan organ pankreas berfungsi secara normal. Tanda gejala penyakit DM tipe 2 diantaranya poliuria, glukosuria, polidipsia, polifagia, penurunan berat badan dan badan terasa lemas. Tanda gejala tersebut terdapat pada hasil penelitian yang dilakukan oleh Rusdianingseh (2018) menghasilkan tema mengenai respon fisik terhdap DM bahwa partisipan seluruhnya mengalami keluhan fisik diataranya lemas, mudah mengantuk, kaki terasa kesemutan, pandangan kabur, sering kencing dan mudah lapar. Tingginya kadar gula darah dapat mengakibatkan penderita DM akan merasa mudah lelah, karena kadar gula darah yang tinggi akan mengakibatkan penderita menjadi dehidrasi dan penderita akan merasa cepat haus sehingga asupan cairan menjadi meningkat sehingga output urine jadi ikut meningkat. Penelitian ini melibatkan 6 orang lansia semuanya mengungkapkan badan terasa lemas, banyak buang air kecil, penurunan berat badan, sering merasa haus pada saat pertama kali terkena DM dan saat partisipan mengalami kekambuhan.

Pusing kepala disebabkan oleh gula darah mengalami penurunan rata-rata $50-70$ $\mathrm{mg} / \mathrm{dL}$. Glukosa merupakan nutrisi untuk otak, oleh karena itu apabila gula darah sedang mengalami penurunan organ yang pertama kali terkena dampaknya adalah sistem syaraf pusat dengan mengeluarkan respon tubuh yaitu pusing. Selain pusing, pasien yang mengalami hipoglikemia salah satunya tubuh menjadi gemetar, respon ini disebabkan oleh hipersekresi insulin yang mengakibatkan sel mengambil gula darah yang banyak dan menyebabkan pasien mengalami hipogikemia. Kondisi ini dialami oleh seluruh partisipan sebagai respon fisik pertama kali terkena diabetes dan keluhan saat mengalami kekambuhan. Penelitian ini juga didukung oleh penelitan Rusdianingseh (2018) bahwa hasilnya juga mengatakan respon fisik yang dirasakan oleh partisipannya diantaranya adanya lemas, mudah mengantuk, kaki terasa kebal/kesemutan, pandangan kabur, mudah lapar dan banyak buang air kecil.

\section{Respon Psikologis yang Dialami Penderita DM}

Respon psikologis terbagi menjadi 5 tahapan, yaitu terdiri dari denial (penyangkalan), anger (marah), bargaining (penawaran), depression (depresi) dan acceptance (penerimaan). Penyangkalan merupakan tahap awal respon psikologis yang dialami oleh tiap individu, sehingga ketika diagnosis yang sudah diberikan oleh tenaga kesehatan namun dalam kondisi tersebut individu akan mencari saran dari pihak yang lain. Kondisi tersebut terjadi pada partisipan, mereka menyangkal dengan berbagai macam ungkapan ketika pertama kali mengetahui terkena DM.

Kemarahan adalah perasaan kesal yang timbul sebagai respon dalam situasi yang dianggap sebagai ancaman. Kemarahan merupakan hal yang wajar pada saat seseorang merasa kehilangan. Kemarahan sering kali muncul pada individu yang dipicu oleh perasaan ketidakberdayaan dan keputusasaan, saat individu mengalami hal tersebut merupakan tahap yang normal dalam menghadapi penyakit yang diderita. Seseorang dengan DM tipe 2 membutuhkan perawatan seumur hidup yang akhirnya mengakibatkan penderita mengalami perubahan psikologis. Kondisi ini terjadi pada 
partisipan ketika mengalami kekesalan pada penyakit diabetes yang tidak kunjung sembuh.

Depresi ini akan terjadi pada individu ketika menyadari bahwa ia akan meninggal atau tidak ada lagi yang bisa dilakukan. Menurut Siregar \& Hidajat (2017) faktor yang berperan terhadap depresi yang mempengaruhi kondisi psikologis penderita diabetes meliitus adalah lamanya masa perawatan yang dijalani oleh penderita dan durasi menderita diabetes yang sudah bertahun-tahun. Perasaan tidak nyaman atau perasaan takut yang dialami oleh individu menyebabkan klien tidak merasa tenang. Pada penelitian ini partisipan mengalami rasa khawatir yang disebabkan oleh penyakit yang tak kunjung sembuh ditambah dengan kondisi gula darah yang tidak stabil.

Tidak sedikit para penderita diabetes yang mengalami kegelisahan karena memikirkan kondisi penyakit diabetes yang akan menyebabkan kematian. Tingkat kecemasan dan memiliki tingkat kebermaknaan hidup yang rendah akan meningkatkan depresi. Jika penderita mengalami kondisi ini akan memperparah kondisi psikologis pada penderita DM tipe 2 terutama pada lansia, karena apabila psikologis sudah mengalami gangguan, maka fisik klien juga akan terganggu. Hal ini juga akan mengakibatkan kadar gula darah menjadi tidak stabil dan masa perawatan akan semakin lama (Setyawati et al., 2020). Namun apabila penderita memiliki koping yang adaptif, penderita diabetes pun akan cepat mengalami proses penerimaan diri dengan baik sehingga kualitas hidup penderita DM tipe 2 akan mengalami peningkatan ke arah yang lebih baik.

Proses penerimaan (acceptance) adalah kondisi dimana penderita berhasil menghadapi konflik emosi terhadap penyakit yang dideritanya dan individu telah memasuki tahap realisasi bahwa kematian tidak dapat dihindari. Menurut Yan et.al., (2017) terdapat hubungan antara penerimaan diri dengan optimisme pada penderita DM. Mekanisme koping yang adaptif akan mengatasi ketidaknyamanan psikologis yang dialami oleh penderita diabetes melitus sehingga proses perawatan diri pun akan tercapai dengan baik. Respon psikologis penerimaan ini terjadi ketika partisipan menyadari bahwa tidak ada hal yang harus diperbuat selain merawat kondisi yang dialaminya dengan baik. Ada beberapa faktor-faktor yang mempengaruhi proses munculnya proses penerimaan penyakit. Hal ini dapat berasal dari faktor internal yang turut mempengaruhi seperti karakteristik/kepribadian individu, keyakinan (hardiness), tingkat religiusitas, motivasi, kesabaran, kondisi keparahan penyakit serta faktor demografi seperti usia dan jenis kelamin, sedangkan faktor eksternal seperti peran dan dukungan keluarga, peran ahli medis, tuntutan pekerjaan, serta kondisi lingkungan sosial dan ekonomi sangat memberikan pengaruh dalam penerimaan (Setyorini \& Supriyadi, 2021).

\section{Kepatuhan terhadap Pengobatan}

Susanti (2018) menyatakan bahwa kepatuhan adalah tingkat perilaku pasien yang setuju terhadap instruksi atau menyatakan bahwa petunjuk yang diberikan dalam bentuk terapi apapun yang ditentukan, baik itu diet, latihan, pengobatan, atau menepati janji pertemuan dengan dokter. Sedangkan ketidakpatuhan merupakan perilaku individu yang gagal untuk menepati rencana asuhan yang diberikan oleh tenaga kesehatan sehingga dapat mengakibatkan hasil secara klinis menjadi tidak efektif. Derajat ketidakpatuhan sangatlah bervariasi tergantung dari pengobatan tersebut apakah pengobatan dalam jangka panjang atau pendek, adanya reaksi obat yang tidak diharapkan, adanya 
kebosanan dalam mengkonsumsi obat, dan lansia merasa tidak kunjung sembuh walaupun lama mengkonsumsi obat.

Lansia juga berpersepsi bahwa dengan mengkonsumsi obat, penyakit DM yang mereka derita bisa sembuh tapi ternyata tidak bisa menyembuhkan, kondisi ini menyebabkan mereka tidak mau mengkonsumsi obatnya lagi. Kondisi ini berdampak pada ketidakpatuhan kepatuhan lansia untuk melakukan managemen terapeutik yang seharusnya dilaksanakan. Hasil penelitian ini juga didukung oleh penelitian Susanti (2018) bahwa dari 30 responden di Puskesmas Sukosewu Kabupaten Bojonegoro tahun 2017, mayoritas responden yaitu sebanyak 30 orang (100\%) tidak patuh dalam melakukan perawatan DM. Pada penelitian ini juga mendapatkan hasil bahwa pemahaman partisipan mengenai cara kerja obat pun menjadi penyebab internal tidak patuhnya untuk mengonsumsi obat, mereka berasumsi bahwa obat DM dapat menyembuhkan dan mengembalikan kondisi tubuh sehat seutuhnya

\section{Kepatuhan terhadap Diet}

Ketidakpatuhan merupakan prilaku seorang pasien yang gagal untuk mengikuti program yang sudah di rencanakan oleh tenaga kesehatan. Perilaku merupakan respon seseorang terhadap stimulus atau rangsangan dari luar. Respon ini terbagi menjadi dua diantaranya yaitu respondent respons ditimbulkan oleh stimulus tertentu (electing stimulation) dan operant respons yang ditimbulkan oleh stimulus reinforcer. Pada tema ini terdapat dua kategori yaitu perilaku tidak melaksanakan diet dan penyebab tidak melaksanakan diet. Prilaku tidak melaksanakan diet ini disebut sebagai prilaku operant respons dimana partisipan tidak bisa menahan keinginan pribadi yaitu tidak mengikuti anjuran diet dan kebosanan menyiapkakan makanan yang sesuai. Hal ini tentu akan berdampak pada tidak stabilnya gula darah. Berdasarkan hasil penelitian ini, sejumlah 6 orang partisipan menyatakan mengetahui bahwa diet harus dilaksanakan dan memiliki niat untuk mematuhinya namun pada pelaksanaannya partisipan tidak melakukan diet. Rata-rata partisipan seluruhnya tidak bisa menahan keinginannya untuk mengonsumsi makanan dan minuman yang banyak mengandung gula, hal ini merupakan perilaku tidak melaksanakan diet.

Selain itu beberapa partisipan mengeluhkan tidak bisa mengikuti diet karena ribet untuk menyiapkan makanannya ditambah dengan kondisi ekonomi tidak bisa mencukupi untuk mematuhi diet yang dianjurkan. Dalam hal ini keluarga ikut andil dalam memberikan asuhan pada penderita setelah ditangani oleh pelayanan kesehatan, sehingga resiko terhadap komplikasi yang serius dapat dicegah dan gula darah menjadi stabil. Keluarga juga menjadi unsur utama dalam penyelesaian masalah pasien, karena dengan adanya dukungan dan motivasi dari keluarga, pasien dapat meningkat motivasinya serta mendapatkan bantuan yang cukup baik dalam melakukan pola hidup sehat (Putri \& Nusadewiarti, 2020). Sedangkan faktor penghambatnya adalah belum terbiasanya pasien dalam menerapkan pola hidup yang sehat seperti makan makanan yang dianjurkan. Selain itu perubahan gaya hidup yang tidak sama seperti sebelumnya juga mengakibatkan ketudakpatuhan penderita DM terhadap diet. Hal ini sesuai dengan penelitian Setyorini (2017) bahwa terjadinya perubahan gaya hidup yang signifikan pada saat sebelum dan sesudah terdiagnosa DM yang menyebabkan stress pada pasien DM. Sehingga ketidakpatuhan kadang menjadi pilihan koping yang diambil oleh pasien DM dalam perawatan dirinya. 


\section{Upaya untuk Mencapai Kesembuhan}

Elemen prilaku sakit salah satunya adalah tahap pembuatan keputusan, dalam hal ini asumsi peranan sakit pada individu akan membuat keputusan memerlukan pengobatan yang kemudian akan mencari informasi dari orang sekitar untuk mengobati dengan caranya sendiri. Upaya untuk menstabilkan gula darah dengan terapi komplementer pada penelitian ini empat partisipan lansia menyatakan sempat menggunakan berbagai macam pengobatan tradisional atau alternatif. Mereka mengetahui metode pengobatan tersebut karena mendapatkan informasi dari tetangga sekitar dan melihat hasil positif yang dirasakan oleh informan. Hal ini juga sejalan dengan penelitian Ligita et al., (2019) bahwa ada sejumlah faktor yang mempengaruhi mempengaruhi keputusan seseorang untuk mengikuti atau tidak mengikuti terapi yang direkomendasikan seperti keadaan keuangan; waktu; rekomendasi dari kerabat dan teman; alasan fisiologis seperti perubahan dalam tubuh atau gejala yang memburuk; alasan psikologis seperti sebagai takut efek samping dari obat, takut harus menyuntikkan obat dan meremehkan keparahan penyakit; dan masalah kenyamanan dan kepraktisan terapi.

Hasil penelitian menunjukkan bahwa terdapat 5 informan yang melakukan terapi komplementer tidak lagi melanjutkan terapi karena merasa tidak kunjung sembuh dan beberapa lainnya merasa tidak membaik bahkan memperparah kondisi penyakitnya. Padahal kepatuhan dalam melakukan manajemen perawatan diri seperti makan makanan sehat, minum obat secara benar dan teratur menjadi kunci utama dalam mencegah perkembangan penyakit ke arah lebih berat yang menimbulkan komplikasi sehingga kualitas hidup pasien DM tipe 2 bisa tetap meningkat (Azmiardi, 2020).

\section{Harapan Penyandang DM}

Harapan adalah konsep yang menghubungkan dengan spiritualitas, dengan kata lain merupakan proses antisipasi yang melibatkan interaksi yang diarahkan menuju pemenuhan kebutuhan dimasa yang akan datang dan memiliki makna secara personal. Ketika seseorang memiliki sikap terhadap sesuatu untuk berharap dan melihat ke depan, maka akan timbul sebuah harapan. Hasil penelitian menujukan adanya harapan klien DM pada diri sendiri yaitu keinginannya untuk mendapatkan kesembuhan dari penyakit yang dideritanya agar bisa beraktifitas kembali. Pernyataan ini sesuai dengan hasil wawancara yang diungkapkan oleh partisipan mengenai keinginannya untuk sembuh. Putri \& Nusadewiarti (2020) juga mengatakan bahwa Pasien merasa sering merasa khawatir karena kesehatannya yang memburuk dan aktivitas sehari-hari menjadi terganggu. Pasien berharap sakitnya dapat disembuhkan dan dapat beraktivitas kembali seperti biasanya.

\section{SIMPULAN}

Penelitian ini mengidentifikasi 6 tema, yaitu: 1) respon fisik yang dialami penderita DM; 2) respon psikologis yang dialami penderita DM; 3) kepatuhan terhadap pengobatan; 4) kepatuhan terhadap diet; 5) upaya untuk mencapai kesembuhan; 6) harapan penyandang DM.

Berdasarkan pernyataan enam informan yang mengalami DM, mereka mengalami beberapa masalah fisik dan psikologis, ada yang tidak patuh dengan diet dan cara partisipan mengatasi masalah ada yang menggunakan obat farmakologis dan juga non farmakologis. Meskipun sudah lama menderita DM, hampir semua partisipan berharap untuk sembuh dari penyakitnya. 


\section{SARAN}

Disarankan kepada penyedia pelayanan kesehatan agar melakukan konseling dan pendidikan kesehatan yang berkelanjutan pada klien lansia terutama keluarga mengenai pentingnya mengendalikan gula darah untuk mencegah terjadinya komplikasi yang berat, karena ketika orang terlibat dalam program pendidikan yang ada hubungan positif dengan hasil kesehatan maka akan meningkatkan kesehatan dan kesejahteraan mereka secara keseluruhan.

\section{DAFTAR PUSTAKA}

Anwar, L., \& Karota, E. (2019). Efektifitas Pendampingan: Konseling Kesehatan terhadap Pengendalian Kadar Gula Darah pada Klien dengan Diabetes Mellitus. Jurnal Ilmu Keperawatan Jiwa, 2(3), 129-138. http://dx.doi.org/10.32584/jikj.v2i3.390

Azmiardi, A. (2020). Hubungan Pengetahuan dengan Praktik Perawatan Diri pada Pasien Diabetes Mellitus Tipe 2 di Surakarta. Jurnal Ilmu Kesehatan Masyarakat Berkala, 2(1), 18-22. https://doi.org/10.32585/jikemb.v2i1.812

Damayanti, S., \& Rahil, N. H. (2018). Efektivitas Diabetes Self Management Education (DSME) terhadap Kejadian Kaki Diabetik Non Ulkus. Jurnal Medika Respati, 13(3), 19-28. https://doi.org/10.35842/mr.v13i3.186

IDF Atlas. (2019). IDF Diabetis Atlas 9th Edition. https://www.diabetesatlas.org

Kementrian Kesehatan RI. (2018). Hasil Utama Riset Kesehatan Dasar (Riskesdas) 2018. https://www.kemkes.go.id

Ligita, T., Wicking, K., Francis, K., Harvey, N., \& Nurjannah, I. (2019). How People Living with Diabetes in Indonesia Learn about Their Disease: A Grounded Theory Study. Plos One, 14(2), 1-19. https://doi.org/10.1371/journal.pone.0212019

Putri, Y. T. P., \& Nusadewiarti, A. (2020). Penatalaksanaan Pasien Diabetes Melitus Tipe 2 dengan Neuropati dan Retinopati Diabetikum Melalui Pendekatan Kedokteran Keluarga. Medula, 9(4), 631-638. http://juke.kedokteran.unila.ac.id/index.php/medula/article/view/2597\%0A

Rosyid, N., Fahrun, Kristinawati, B., \& Ayu Kurnia, D. (2020). Kadar Glukosa Darah Puasa dan Dihubungkan dengan Kualitas Hidup pada Pasien Ulkus Kaki Diabetik. Jurnal Keperawatan Silampari, $\quad 3(2), \quad$ 500-509. https://doi.org/10.31539/jks.v3i2.1131

Rusdianingseh, R. (2018). Pengalaman Respon Klien Diabetes Mellitus Tipe 2 di Kelurahan Srengseng Sawah Jakarta Selatan. The Indonesian Journal of Health Science, 10(1), 1-6. https://doi.org/10.32528/the.v10i1.1447

Setyawati, A., Ngo, T., Padila, P., \& Andri, J. (2020). Obesity and Heredity for Diabetes Mellitus among Elderly. JOSING: Journal of Nursing and Health, 1(1), 26-31. https://doi.org/https://doi.org/10.31539/josing.v1i1.1149

Setyorini, A. (2017). Stres dan Koping pada Pasien Dengan DM Tipe 2 dalam Pelaksanaan Manajemen Diet di Wilayah Puskesmas Banguntapan II Kabupaten Bantul. Health Sciences and Pharmacy Journal, 1(1), 1-9. https://doi.org/https://doi.org/10.32504/hspj.v1i1.3

Setyorini, A., \& Supriyadi. (2021). Koping Pasien DM Tipe 2 Dalam Pelaksanaan Manajemen Perawatan Diri. Jurnal Keperawatan, 13(1), 39-46. https://doi.org/10.32583/keperawatan.v13i1.1097

Siregar, A. (2019). Salah Pemahaman tentang Penyakit Diabetes. 
https://www.golansia.com/salah-pemahaman-tentang-penyakit-diabetes-1298/

Siregar, L. B., \& Hidajat, L. L. (2017). Faktor yang Berperan terhadap Depresi, Kecemasan Kasus Puskesmas Kecamatan Gambir Jakarta Pusat. Jurnal Ilmiah Psikologi MANASA, 6(1),

http://ejournal.atmajaya.ac.id/index.php/Manasa/article/view/169/347

Susanti, D. (2018). Gambaran Kepatuhan Perawatan Kaki pada Penderita Diabetes Mellitus di Puskesmas Sukosewu Kabupaten Bojonegoro. Asuhan Kesehatan Jurnal Ilmiah Ilmu Kebidanan dan Keperawatan, 8(2), 49-54. http://ejournal.rajekwesi.ac.id/index.php/jurnal-penelitiankesehatan/article/view/177

Yan, L. S., Marisdayana, R., \& Irma, R. (2017). Hubungan Penerimaan Diri dan Tingkat Stres pada Penderita Diabetes Mellitus. Jurnal Endurance, 2(3), 312. https://doi.org/10.22216/jen.v2i3.2234 